[5] CRM hlazamy Darvyna: Evolyutsyya klyent-oryentyrovannykh tekhnolohyy. (2006). CRM konsul'tant, 1, 6-11.

[6] Karmynskyy, A. M. (2006). Ynformatsyonnye systemy v ekonomyke. Praktyka yspol'zovanyya. Fynansy ta statystyka, 336.

[7] How companies approach innovation: A McKinsey Global Survey. Available: http://www.mckinsey.com/featured-insights

[8] Kl'oba, L. H. Marketynhovi aspekty vdoskonalennya upravlinnya bankivs'koyu diyal'nistyu. Official web-site of National University “Lviv Polytechnic” Repositary. Available: http://ena.lp.edu.ua:8080/ bitstream/ntb/11394/1/54.pdf

[9] Yskusstvo ekspluatatsyy CRM. Available: http://www.prostobankir.com.ua/it/stati/iskusstvo ekspluatatsii_crm

[10] Official web-site of Microsoft Dynamics CRM. Available: http://crm-consulting.com.ua/

[11] Postanova Pravlinnya Natsional'noho banku Ukrayiny «Pro zatverdzhennya Polozhennya pro zdiysnennya bankamy finansovoho monitorynhu» vid 26.06.2015 № 417. Available: http://zakon3.rada.gov. ua/laws/show/v0417500-15

\title{
ASEAN TENDENCY TO THE REGIONAL LEADERSHIP IN TRADE IN SERVICES
}

\author{
Oleksandr Krinitsyn \\ Department of the world economy and international economic relations \\ Institute of international relations, Taras Shevchenko national university of Kyiv \\ 36/1 Melnikova str., Kyiv, Ukraine, 04119 \\ krinitsyn.alexander@gmail.com
}

\begin{abstract}
Extremely dynamic and significant structural changes are transforming the world economy and international trade. Comparing with analogous experience of economic history it is worth to pay attention not only to the fast speed of global transformation but also to its wide scope that influences practically the whole world.

The shift of economic power from West to East and from North to South, from industrially developed countries to the developing ones, especially Asian, is the obvious base of these transformations. In contrast to the world tendencies of the 20 -th century with two dominant centers namely USA and EU, in the 21-st century the developing Asian countries with more dynamics of development rise on the global arena.

Economies of Association of Southeast Asian Nations (ASEAN) are not an exclusion from these tendencies. Whereas their speed growth in the last four decades was conditioned by high level of industrial production export, the services sector and trade in services began to gain importance not so long ago.

Association of Southeast Asian nations unites ten countries with total population more than 622 million people and total GDP more than 2.6 trillion US dollars. These countries are well integrated into the world economy and successfully gain profit from this integration.

In particular the ASEAN integration helped to raise regional trade flows without trade diversification, to improve trade logistics, to decrease total trade costs and to increase regional investment flows.

The article deals with analysis of values, dynamics and structure of trade in services in Association of Southeast Asian Nations.

A complex analysis of trade in services with respective breakdown into separate branches was carried out. This article analyzes the importance of complex legal-regulatory measures for successful promotion of trade in services within the region as well as with the rest of world.

Keywords: international trade, trade in services, liberalization, Association of Southeast Asian Nations, ASEAN, ASEAN Framework Agreement on Services, AFAS.
\end{abstract}




\section{Introduction}

Today the growing importance of services in the world economy is conditioned by the high demand of consumers and producers as well as by international trade. In proportion to the growth of income the growth of the consumers' demand for personal and recreational services and also service-intensive production takes place, whereas producers search for more specialized and complicated approaches to professional consultations. A part of these claims is satisfied by international trade, because services became an important element of external economic activity in the modern world. The intensification of fragmentation of production processes in the global value chains along with information and telecommunication technologies attainments including the content digitalization allows many kinds of services previously considered as non-tradable across borders appear at international level. At the same time such fundamental services as transport, logistics, telecommunication and financial services are the inalienable component of global value chains surplus and act as the connecting element that gives a possibility to conduct production activities of certain good in several countries. International experience testifies that the expansion of trade in services is connected with an increase of income per capita and with higher productivity.

Services play the important role in other economic sectors as well as in export. That is why many services such as financial, transport and communications are basic and support other production processes. At the same time trade in service can favor the strengthening of competition by guaranteeing access to the essential production resources at lower costs.

\section{Analysis of literary data and the problem statement}

The majority of international organizations deal with the problems and tendencies of trade in services because this sector of economy shows strong dynamics and mobility in modern economic relations.

The World Trade Organization annually publishes World Trade Report [1], International Trade Statistics [2] and Annual Report [3] showing the current tendencies and trade statistics, including trade in services. World Economic Forum issues The Global Enabling Trade Report [4]. UN also publishes an annual report World Economic Situation and Prospects [5].

The official ASEAN webpage contains numerous reports, for example, ASEAN Economic Community 2015: Progress and Key Achievements [6] and ASEAN Integration Report 2015 [7]. At the same time trade statistics with brief information on trade in services concerning values and dynamics can be found under the heading Trade in Services [8].

\section{Aim and tasks of research}

The aim of this article is to analyze the structure and dynamics of international trade in services in Association of Southeast Asian Nations. To define factors that hamper the trade in services growth in ASEAN region and the possibility for further integration.

\section{Materials and methods of research}

Extremely dynamic and significant structural changes are transforming the world economy and international trade. Comparing with analogous experience of economic history it is worth paying attention not only to the fast speed of global transformations but also to their wide scope that influences practically the whole world.

The shift of economic power from West to East and from North to South, from industrially developed countries to the developing ones, especially Asian, is the obvious base of these transformations. In contrast to the world tendencies of the 20-th century with two dominant centers namely USA and EU, in the 21-st century the developing Asian countries with more dynamics of development come into sight on the global arena.

Economies of ASEAN countries are not an exclusion from these tendencies. Whereas their growth speed in the last four decades was conditioned by the high level of industrial production export, the services sector and trade in services began to gain importance not so long ago. In 2010 the share of services on average was more than $40 \%$ in total value added and $50 \%$ in employment 
of the ASEAN member states. The share of services in export in terms of value added steadily increases in all ASEAN countries except for Indonesia.

Association of Southeast Asian Nations unites ten countries with total population of more than 622 million people and total GDP more than 2.6 trillion US dollars. These countries are well integrated into the world economy and successfully gain profit from this integration. In particular ASEAN integration helped to raise regional trade flows without trade diversification, to improve trade logistics, to decrease total trade costs and to increase regional investment flows. Noting the ambitious aim to form the Economic Community (AEC) by 2015, ASEAN intended to deepen its regional integration and planned the development up to the year 2025 on this base [9].

The graph of external trade in services dynamics of ASEAN countries soundly demonstrates feasibility of the declared ambitions (Fig. 1)

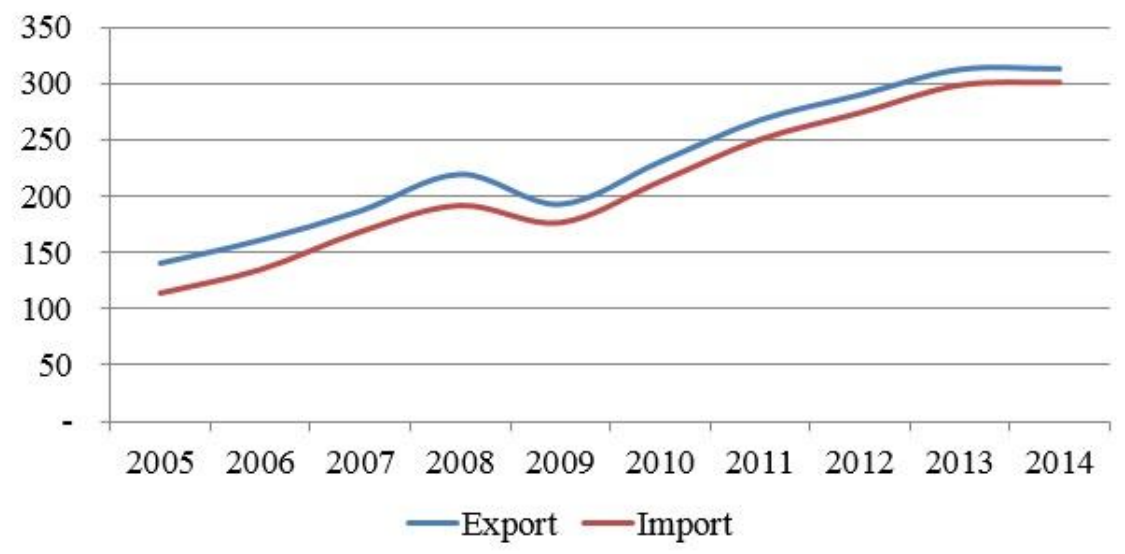

Fig. 1. External trade in services dynamics of ASEAN countries 2005-2014, billion US dollars Source: based on the International Trade Center data [2]

Services have a share of $40-70 \%$ in gross national income of economies of ASEAN countries. ASEAN had a share of $12 \%$ in the total world trade in services or 615 billion dollars in 2014 [10]. At the same time during the last two years the foreign direct investments (FDI) in the services sector was nearly $60 \%$ from the total FDI volume that clearly points the importance of this sector.

ASEAN member states recognize the node role of the services sector in their development and place the trade in services in the center of their integration agenda. Governments in the region have realized the fundamental role of services for economic growth and job creation, and have embarked on a large-scale regional integration program, aimed to promote the free flow of services. The services integration in the region was firstly documented by signing the Framework Agreement on Services (ASEAN Framework Agreement on Services, AFAS) in 1995 [11], three years after signing the agreement on goods within the ASEAN Free Trade Area (AFTA). The AEC Blueprint accepted in 2007 presupposed the brave and ambitious vision of deep integration when goods and services, investments and qualified work force will freely move through the boundaries of ASEAN countries already in 2015. The detailed aims were elucidated in AFAS [12] and AEC Blueprint that ground the regional trade in services stimulation.

\section{Results of researches}

The results described in AEC report [6] can be generally considered as the positive ones taking into account the data of the dynamics of trade in services within the region as well as with the rest of world (Table 1).

Based on the statistical data of 2014 it is possible to separate the main branches forming the structure of external trade in services of the Association. The top 3 spheres of the external trade in services are: travel services $(35.4 \%)$, other business services $(23.2 \%)$, transport services $(21.1 \%)$ 
which together form almost $80 \%$ of the total export value. It is worth noting that trade in services within the region does not exceed $20 \%$ of the total value that testifies the developed trade connections and demand for services produced in ASEAN outside the Association.

Table 1

Average annual growth of ASEAN service trade in 2010-2014 years

\begin{tabular}{|c|c|c|c|c|}
\hline \multirow{2}{*}{ Category } & \multicolumn{2}{|c|}{ Average annual growth } & \multicolumn{2}{|c|}{$\begin{array}{c}\text { Average annual intraregional } \\
\text { growth }\end{array}$} \\
\hline & Export & Import & Export & Import \\
\hline $\begin{array}{l}\text { Manufacturing services on physical inputs } \\
\text { owned by others }\end{array}$ & $9,4 \%$ & $18,7 \%$ & $\mathrm{n} / \mathrm{d}^{*}$ & $\mathrm{n} / \mathrm{d}^{*}$ \\
\hline Maintenance and repair services & $6,6 \%$ & $12,0 \%$ & $11,0 \%$ & $17,5 \%$ \\
\hline Transport service & $3,3 \%$ & $6,5 \%$ & $5,6 \%$ & $4,6 \%$ \\
\hline Travel service & $12,5 \%$ & $8,4 \%$ & $8,2 \%$ & $10,2 \%$ \\
\hline Construction service & $6,9 \%$ & $16,0 \%$ & $13,9 \%$ & $28,3 \%$ \\
\hline Insurance and pension service & $5,0 \%$ & $5,6 \%$ & $16,8 \%$ & $13,7 \%$ \\
\hline Financial service & $13,1 \%$ & $11,1 \%$ & $4,6 \%$ & $-0,8 \%$ \\
\hline Charge for the use of intellectual property & $30,5 \%$ & $7,5 \%$ & $11,7 \%$ & $11,3 \%$ \\
\hline $\begin{array}{l}\text { Telecommunication, computer and } \\
\text { information service }\end{array}$ & $8,8 \%$ & $17,3 \%$ & $12,2 \%$ & $11,3 \%$ \\
\hline Other business service & $11,2 \%$ & $9,9 \%$ & $11,9 \%$ & $9,9 \%$ \\
\hline Personal, cultural and recreational service & $7,6 \%$ & $14,5 \%$ & $8,8 \%$ & $18,9 \%$ \\
\hline Government goods and services & $4,5 \%$ & $0,8 \%$ & $14,5 \%$ & $21,1 \%$ \\
\hline Total & $9,4 \%$ & $8,2 \%$ & $8,6 \%$ & $8,8 \%$ \\
\hline
\end{tabular}

Source: Based on the data of ASEAN Statistics service [8]; *-No data

Despite the negative balance of the external economic activity of the region, services export grew in the last years more dynamically than import. So in the period of 2010-2014 the major average speed of export growth was demonstrated by the following branches: charge for the use of intellectual property (30.5\%); financial services (13.1\%) and travel services (12.5\%). Speaking about import the leading branches during the analogous period of time were: manufacturing services on physical inputs owned by the others $(18.7 \%)$; telecommunication, computer and information services $(17.3 \%)$ and construction services $(16.0 \%)$. In total export grew on average by $9.4 \%$ whereas import by $8.2 \%$ per annum, that diminished the negative balance in trade in services from 15.2 to 8.2 billion dollars during the years 2010-2014.

The most dynamic export branches within ASEAN were: insurance and pension services $(16.8 \%)$; government goods and services $(14.5 \%)$ and construction services (13.9\%), import: construction services $(28.3 \%)$, government goods and services $(21.1 \%)$ and personal, cultural recreational services (18.9\%).

Based on this analysis it is possible to reveal the stable growing tendency that testifies the intensification of regional trade in services and growing regions' role in becoming an influential 
player in this sphere. It is worth noting that such speed wouldn't have been possible without correspondent support by the structural agreements as AFAS and its permanent improvement as well as negotiations regarding Free Trade Areas with the neighboring countries.

Despite these possibilities ASEAN countries have not yet realized their potential in services sphere taking into account their level of income and development. In general, paying attention to the significant progress in commitments on the trade in services integration, many steps must be done to complete the realization of aims declared in AEC Blueprint.

At the same time ASEAN member states mainly export "traditional services" such as transport and travel services. The attempts to search new possibilities in services sphere such as information technologies (IT) and business services were less successful. Singapore and Philippines are the main exclusions in this region. The last year's import of IT-services and outsourcing business-processes in the Philippines can be considered as a success-story. The significant growth of export of professional and other business services from Singapore began in the middle 90-th [13].

The ASEAN economies accumulated valuable experience for reformation of its services sector which is very useful for regional integration. The main conclusion is the fact that national governments play an important role not only in the reformation of regional and international integration agenda but also in support of internal reformation process. The governments must closely collaborate with the private sector in order to favor the development of services sector competitiveness by internal legal base and other additional political measures. The node elements of this process is the establishment of standards, accreditation processes and also measures on the quality control that give the possibility to favor the trade in services, guaranteeing the protection of national producers.

\section{Conclusions}

In future, with the growth of ASEAN economies to the average and above average level of income the services sector will gain more importance as a source of employment growth, mainly because the productivity growth in services sector results in the productivity growth in other sectors of the economy.

The completion of the intraregional liberalization in trade in services and investments movement, as it is provided by the AEC Blueprint, will make a base for the formation of ASEAN Economic Community. It will start the process of residuary limitations elimination for market access and elimination of discriminatory measures, including the ones concerning foreign capital.

Elimination of quantitative and discriminatory limitations or formal limitation is not sufficient for the regional trade in services integration if legal barriers are not included in negotiations agenda. Even if commitments on services sector are completely realized some limitations may remain. While eliminating the quantitative and discriminatory limitations favoring the shortening of the formal barriers to trade within the ASEAN agreement, the legal barriers will remain. The attention was concentrated on the elimination of formal barriers to trade and investments in services sphere of the region, but the ASEAN countries still pay the insignificant attention to the coordinated regulatory policy.

Legal-regulatory collaboration can be more important for ASEAN countries. Despite the fact that regulatory questions are mainly outside the AFAS agreement, the process of services integration in ASEAN can play a positive role in increasing the regulation and management quality in the services sphere. For all ASEAN members states, excluding Singapore, the legal questions remain faintly touched since the moment of Agreement validation. For the countries with the low-income level, the problems of regulation quality improvement remain urgent for today. The support of more influential Association partners as well as of institutions with appropriate level of knowledge and experience is necessary to overcome these problems.

\section{References}

[1] World Trade Report. The World Trade Organization. Available at: https://www.wto.org/english/ res_e/reser_e/wtr_e.htm 
[2] WTO International Trade Statistics. The World Trade Organization. Available at: https://www. wto.org/english/res_e/statis_e/its_e.htm

[3] WTO Annual Report. The World Trade Organization. Available at: https://www.wto.org/english/res_e/reser_e/annual_report_e.htm

[4] The Global Enabling Trade Report (2014). World Economic Forum. Available at: http://www. weforum.org/reports/global-enabling-trade-report-2014

[5] World Economic Situation and Prospects (2016). UNITED NATIONS. Available at: http://www. un.org/en/development/desa/policy/wesp/

[6] ASEAN Economic Community (2015). Progress and Key Achievements (2015). ASEAN. Available at: http://www.asean.org/?static_post=asean-economic-community-2015-progress-and-keyachievements-2

[7] ASEAN Integration Report (2015). ASEAN. Available at: http://www.asean.org/?static_post=asean-integration-report-2015

[8] Sluzhba statystyky ASEAN po torgovle uslugamy. ASEAN. Available at http://www.asean. org/?static_post=asean-trade-in-services

[9] Obzor ekonomycheskogo sodruzhestva ASEAN. ASEAN. Available at: http://www.asean.org/ asean-economic-community/

[10] Baza dannyyh mezhdunarodnogo torgovogo centra. Trade Map. Available at: http://www.trademap.org/tradestat/index.aspx

[11] Obzor Ramochnogo soglashenyja ASEAN po torgovle uslugamy. ASEAN. Available at: http:// investasean.asean.org/index.php/page/view/asean-free-trade-area-agreements/view/757/newsid/870/asean-framework-agreement-on-services.html

[12] Tekst Ramochnogo soglashenyja ASEAN po torgovle uslugamy. ASEAN. Available at: http:// investasean.asean.org/files/upload/Doc\%2008\%20-\%20AFAS.pdf

[13] Sovmestnyyj doklad Sekretaryata ASEAN i Myrovogo Banka ASEAN Services Integration Report (2015). ASEAN. Available at: http://www.asean.org/storage/images/2015/November/asean-services-integration-report/ASEAN_Services_Integration_Report.pdf 